\title{
Note on a find of a crossopterygian head (Pisces), upper Westphalian D, Sydney Coalfield, Nova Scotia, Canada
}

\author{
Erwin L. Zodrow, Andrew P. Beaton and Greg Smith \\ Department of Geology, University College of Cape Breton \\ Sydney, Nova Scotia B1P 6L2, Canada
}

Date received August 2, 1988

Date accepted November 22, 1988

Although documented palaeontologic collections from the Carboniferous System in Nova Scotia and New Brunswick, Canada, date back at least to 1840, only some scales and bones of megalichthiid crossopterygian fish are described and figured (Gardiner, 1966, p. 86). The newly discovered find of a nearly complete crossopterygian head with adjoining scales in life position is significant as few Late Carboniferous crossopterygians are known and this specimen is well preserved.

The fossil came from a ca. $20 \mathrm{~cm}$ thick stromatolitic limestone band, representing a brackish ephemeral palaeolake during a time of non-peat deposition in the Sydney Basin (Vasey and Zodrow, 1983). Stratigraphically, the algal limestone is located about $10 \mathrm{~m}$ above the Harbour Seam (Zodrow, 1985, Text-Fig. 1), in the upper part of the Linopteris obliqua floral zone (Zodrow and Vasey, 1986, Fig. 18). The strata of this section are homotaxial with the upper Westphalian D stage (Zodrow and Cleal, 1985, Fig. 5), or approximately 300 million years old (Forster and Warrington, 1985).

A limestone slab of ca. $70 \mathrm{~cm}$ length contains the fossil fish which consists of the head and adjoining articulate scales showing a lateral line and fins. After preparation, the dorsal side of the fish head is approximately $13 \mathrm{~cm}$ long and only slightly flattened laterally. Only a few frontal teeth are preserved, they are small (3-5 mm long) and conic in shape. The scales are rhomboid in outline and are up to $2.5 \mathrm{~cm}$ long and $1.8 \mathrm{~cm}$ wide, and much of the external surface is covered by shiny cosmine. The cosmine is missing around the scale margins, from which it is separated by a distinct groove (Fig. 1).

Crossopterygian heads are well known and even Megalichthys is now well described (Jarvik, 1966; Bjerring, 1972; Schultze, 1974).

This new find shows clearly that two articulations are present. The articulation between the ethmosphenoid and oticooccipital divisions of the skull are represented as ' 1 ' in Figure 2a, and ' 2 ' is the connection between the head and the trunk. Further, the gill flaps are oblong in shape and large, about $6 \mathrm{~cm}$ long and $4 \mathrm{~cm}$ wide.

Assignment to a species is not possible. The specimen could be referred to the Subfamily Megalichthyniae, cf. Megalichthys sp., if the specimen can be shown to lack apineal foramen, and if it has a complex articulation between the dermal parietal and the frontal shields, and a medial branch running from the intertem-

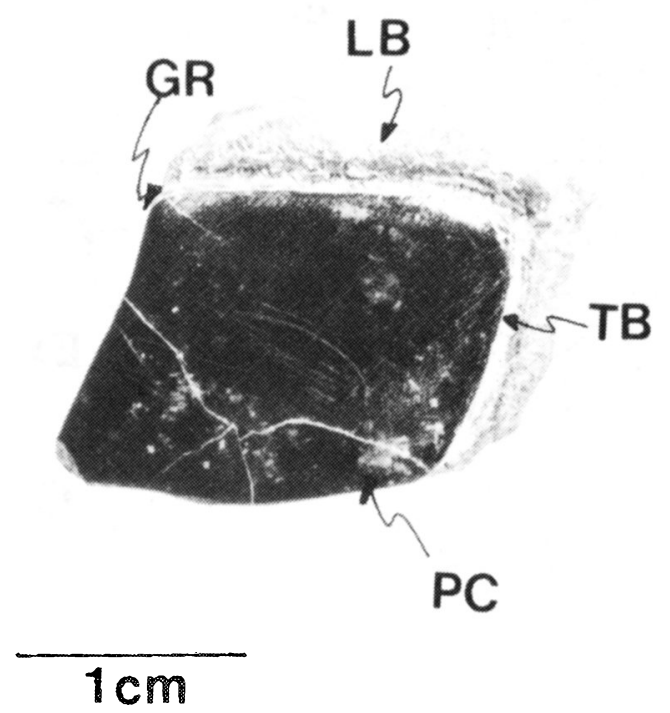

Fig. 1. External surface of a scale detached from the dorsal part of the specimen; GR - groove, LB - lamellar bone, TB - trabecular bone, PC - porous cosmine. 


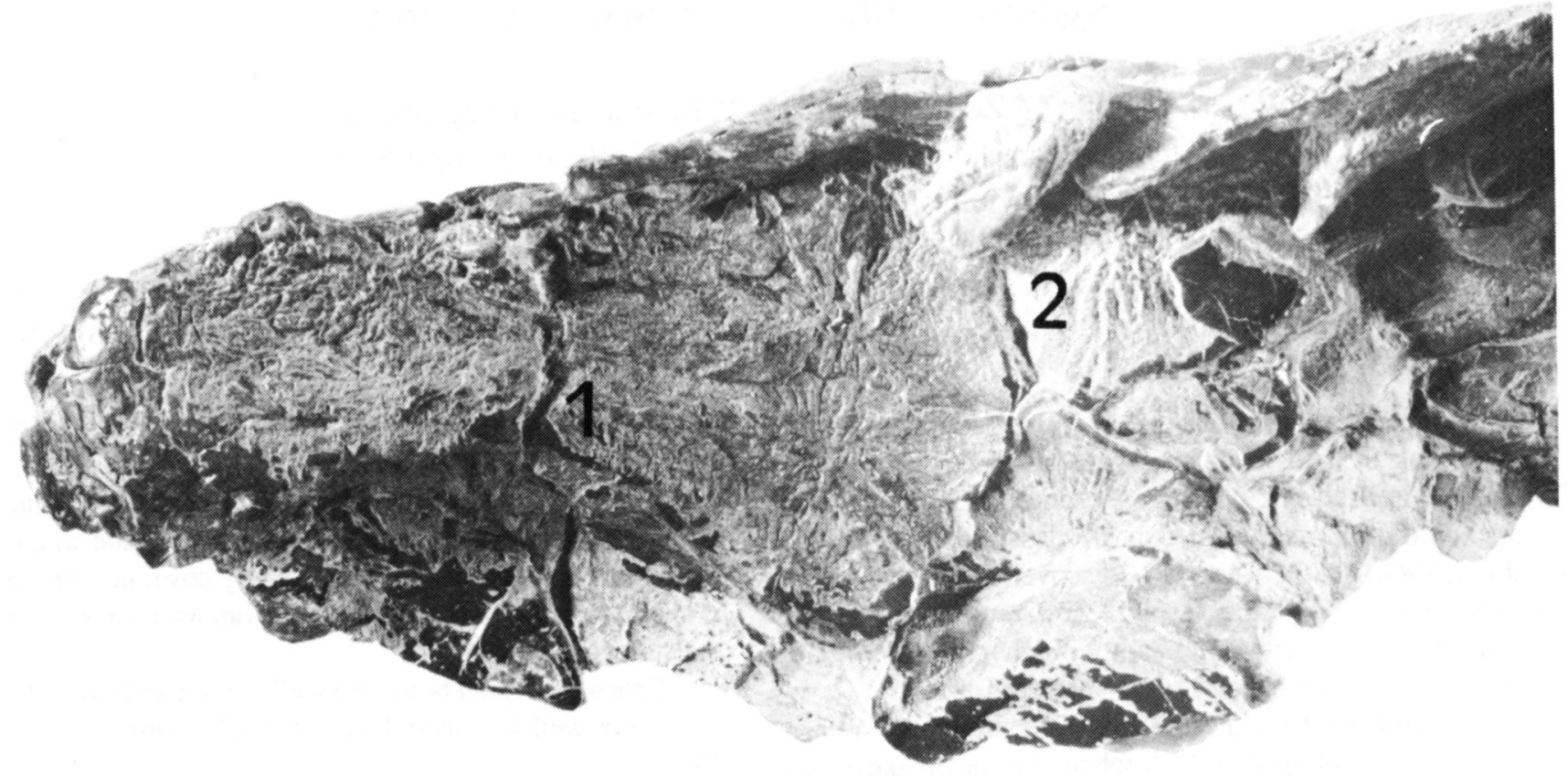

NMC 40606

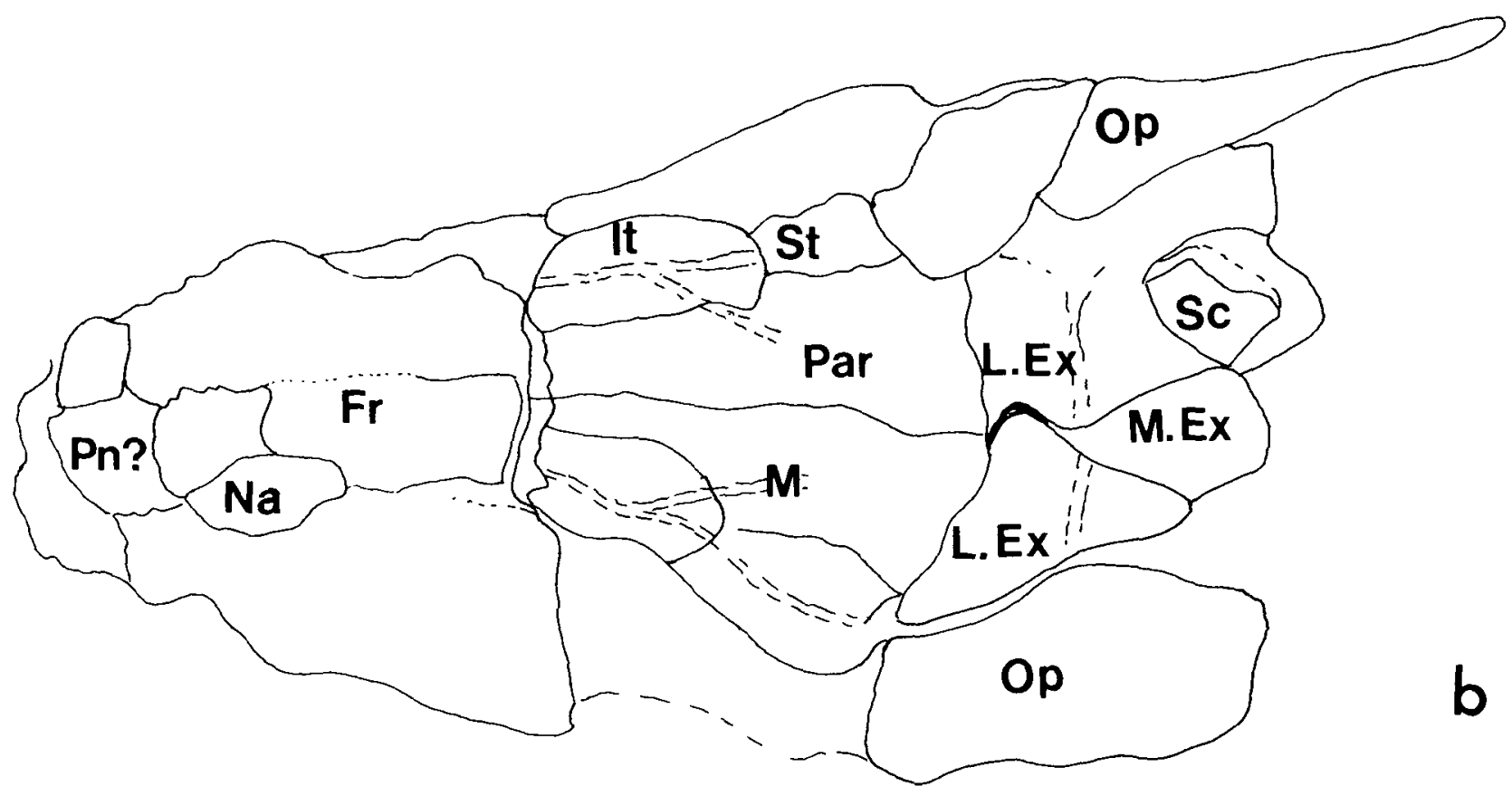

Fig. 2. (a) Crossopterygian head, dorsal view of the specimen NMC 40606; Sydney Coalfield, Nova Scotia, Canada; 1 articulation between ethmosphenoid and otico-occipital divisions of the head, and 2 articulation between parietal shield and extrascapulars. Slightly smaller than natural size. (b) Overlay of Figure 2 showing Fr - frontal, It - intertemporal, L.Ex - lateral extrascapular, M - medial branch of lateral-line canal into parietal, M.Ex - median extrascapular, Na - nasal, Op - opercular, Par - parietal shield, Pn - postrostrals, Sc - in situ scale, St - supratemporal. 
poral into the centre of the parietal (Bjerring, 1972). Two contacting lateral extrascapulars are noted (Fig. 2b) which are present in some Megalichthys. Exclusion from Ectosteorhachis is as yet not ruled out either (Long, 1985). The specimen is now being fully studied to clarify these and some other questions and results will be communicated in a future publication.

The fossil was discovered by the junior authors and bears the catalogue number NMC 40606 of the National Museum of Natural Sciences, Paleobiology Division, Ottawa, Canada. Financial assistance by the Museum and technical help with the MS, especially Figure $2 b$, by Dr. J.A. Long are gratefully acknowledged.

BJERRING, H.C. 1972. Morphological observations on the exoskeletal skull roof of an osteolepiform from the Carboniferous of Scotland. Acta Zoologica, Stockholm, 53, pp. 73-92.

FORSTER, S.C. and WARRINGTON, G. 1985. Geochronology of the Carboniferous, Permian and Triassic. In The Geochronology of the Geological Record. Edited by N. Snelling. Geological Society of London, Memoir 10, pp. 99-113.

GARDINER, B.G. 1966. Catalogue of Canadian fossil fishes. Contribution No. 68, Royal Ontario Museum, University of Toronto, p. 154.
JARVIK, E. 1966. Remarks on the structure and snout in Megalichthys and certain other rhipidistid crossopterygians. Arkiv foer Zoologi, 19, pp. 41-98.

LONG, J.A. 1985. A new osteolipidid fish from the Upper Devonian Gogo Formation, Western Australia. Records of the Western Australian Museum, 12, pp. 361-377.

SCHULTZE, H.-P. 1974. Osteolepidide Rhipidistia (Pisces) aus dem Pennsylvanian von Illinois, USA. Neues Jahrbuch für Geologie und Paläontologie Abhandlungen, 146, pp. 29-50.

VASEY, G.M. and ZODROW, E.L. 1983. Environmental and correlative significance of a non-marine algal limestone (Westphalian D), Sydney Coalfield, Cape Breton Island, Nova Scotia. Maritime Sediments and Atlantic Geology, 19, pp. 1-10.

ZODROW, E.L. 1985. Odontopteris Brongniart in the Upper Carboniferous of Canada. Palaeontographica, AbteiLung B, 196, pp. 79 110.

ZODROW, E.L. and CLEAL, C.J. 1985. Phyto- and chronostratigraphical correlations between the late Pennsylvanian Morien Group (Sydney, Nova Scotia) and the Silesian Pennant Measures (south Wales). Canadian Journal of Earth Sciences, 22, pp. 1465-1473.

ZODROW, E.L. and VASEY, G.M. 1986. Mabou Mines section: Biostratigraphy and correlation (Pennsylvanian Pictou Group, Nova Scotia, Canada). Journal of Paleontology, 60, pp. 208-232. 